\title{
Pengaruh Pengalaman Petani dan Pengaruh Orang Lain terhadap Adopsi Mesin Tanam Rice Transplanter di Kecamatan Mojolaban Kabupaten Sukoharjo
}

\section{The Influence of Farmer's Experience and Other People's Influence to Rice Transplanter Planting Machine Adoption in Mojolaban Sub-District Oo Sukoharjo District}

Catur Munawaroh, Suminah, Hanifah Ihsaniyati

Program Studi Penyuluhan dan Komunikasi Pertanian Fakultas Pertanian

Universitas Sebelas Maret

J1. Ir. Sutami No.36 A Kentingan Surakarta 57126 Telp/Fax (0271) 637457

Email :caturmunawarah@gmail.com

\begin{abstract}
This research aimed to observe the farmer's experience, other people's influence, farmer's attitude to the adoption of rice transplanter planting machine and farmer's adoption to the rice transplanter planting machine is Mojolaban Sub-district of Sukoharjo District and to observe the effect of farmer's experience, other people's influence and attitude in partially and simultaneously to the adoption of rice transplanter planting machine in Mojolaban Sub-district of Sukoharjo District. The basic method used was qualitative. The research location was determined as purposive in Mojolaban District. The sampling was done using proportional random sampling research method with the number of 60 respondents. The data collection technique was using observation, interview, and documentation. The data analysis method was using path analysis method.The research result showed that farmer's experience in Mojolaban Sub-district was low, other people's influence was rare, farmer's attitude to the adoption of rice transplanter planting machine was disagree and farmer's adoption to the rice transplanter planting machine was never adopt. Partially, farmer's experience significantly effected to the adoption of rice transplanter planting machine directly greater than the attitude, the influence of other people has no significant effect on the adoption of rice transplanter planting machines and the attitude of farmers has a significant effect on the adoption of rice transplanter planting machines in Mojolaban District, Sukoharjo Regency. Farmer's experience, other people's influence and attitude simultaneously significantly affected to the adoption of rice transplanter planting machine in Mojolaban Sub-district of Sukoharjo District.
\end{abstract}

Keyword: Adoption, Farmer's Experience, Other People's Influence, Transplanter

\begin{abstract}
Abstrak: Penelitian ini bertujuan untuk mengkaji pengalaman petani, pengaruh orang lain, sikap petani terhadap adopsi mesin tanam rice transplanter dan adopsi petani terhadap mesin tanam rice transplanter di Kecamatan Mojolaban Kabupaten Sukoharjo dan untuk mengkaji pengaruh pengalaman petani, pengaruh orang lain dan sikap secara parsial dan simultan terhadap adopsi mesin tanam rice transplanter di Kecamatan Mojolaban Kabupaten Sukoharjo. Metode dasar penelitian yaitu kuantitatif.Lokasi penelitian ditentukan secara purposive (sengaja) yaitu di Kecamatan Mojolaban.Penentuan sampel dilakukan dengan menggunakan metode penelitian proportional random sampling dengan jumlah 60 responden. Teknik pengumpulan data menggunakan observasi, wawancara serta dokumentasi.Metode analisis data dengan menggunakan path analysis. Hasil penelitian menunjukkan bahwa pengalaman petani di Kecamatan Mojolaban yaitu rendah, pengaruh orang lain yaitu jarang, sikap petani terhadap adopsi mesin tanam rice transplanter yaitu kurang setuju dan adopsi petani terhadap mesin tanam rice transplanter yaitu tidak pernah mengadopsi. Secara parsial pengalaman petani berpengaruh signifikan terhadap adopsi mesin tanam rice transplanter secara langsung lebih besar jika dibandingkan melalui sikap, pengaruh orang lain berpengaruh tidak signifikan terhadap adopsi mesin tanam rice transplanter dan sikap petani berpengaruh signifikan terhadap adopsi mesin tanam rice transplanter di Kecamatan Mojolaban Kabupaten Sukoharjo. Pengalaman petani, pengaruh orang lain dan sikap secara simultan berpengaruh signifikan terhadap adopsi mesin tanam rice transplanter di Kecamatan Mojolaban Kabupaten Sukoharjo.
\end{abstract}

Kata Kunci: Adopsi, Pengalaman Petani, Pengaruh Orang Lain, Transplanter 


\section{PENDAHULUAN}

Pangan memegang peranan penting dalam perkembangan pertanian Indonesia.Berbagai upaya dilakukan pemerintah untuk menuju kondisi ketahanan pangan nasional.Salah satunya pemerintah membuat kebijakan menetapkan Pencapaian Swasembada Berkelanjutan Padi dan Jagung serta Swasembada Kedelai yang harus dicapai dalam waktu 3 (tiga) tahun (Permentan, 2015).Menteri Pertanian telah mengeluarkan Pedoman Upaya Khusus (UPSUS) Peningkatan Produksi Padi, Jagung dan Kedelai melalui Program Perbaikan Jaringan Irigasi dan Sarana Pendukungnya.Salah satu tujuan dibuatnya pedoman tersebut yaitu untuk menyediakan kebutuhan prasarana dan sarana pertanian berupa air irigasi, benih, pupuk dan alat mesin pertanian (alsintan) dan sarana produksi lainnya.

Penyediaan kebutuhan sarana dan prasarana sangat dibutuhkan guna mendukung kegiatan peningkatan produksi pertanian.Menurut Romadi (2016) kebutuhan tersebut berupa air, irigassi, benih, pupuk dan alat mesin pertanian (alsintan) dan sarana produksi lainnya.Penyediaan alsintan berupa traktor roda dua, mesin tanam (rice transplanter), pompa air dan combine harvester untuk menjamin pengolahan lahan, penanaman, pengairan yang serentak dalam areal yang luas dan pemanenan.

Salah satu mesin pertanian sebagai sarana penunjang yang diberikan pemerintah yaitu mesin tanam rice transplanter. Semenjak tahun 2012 di Kabupaten Sukoharjo telah memiliki mesin tanam rice transplanter kemudian pada tahun 2015 bantuan dari pemerintah berupa alsintan termasuk rice transplanter bertambah. Petani sering kali mengeluarkan biaya yang cukup besar untuk proses produksinnya sedangkan hasil produksinya tidak dapat maksimal, sehingga petani tidak memiliki simpanan yang lebih. Adanya mesin tanam rice transplanter ini dapat menghemat waktu, biaya serta tenaga pengeluaran petani dalam proses produksinya. Sehingga akhirnya target produksi yang telah ditetapkan akan dapat diwujudkan, dan petani pun semakin sejahtera.

Keberhasilan pengadaan alsintan memerlukan sikap yang positif dari petani.Kondisi petani akan berpengaruh terhadap sikap petani sehingga dapat mempengaruhi adopsi mesin tanam rice transplanter. Tingkat adopsi petani terhadap mesin tanam rice transplanter tidak terlepas dari faktor-faktor yang mempengaruhinya. Pengalaman petani dan pengaruh orang lain akan mempengaruhi sikap petani. Sikap petani itu sendiri akan dilihat dari segi kognitif, afektif dan konatif. Oleh karena itu perlu adanya penelitian mengenai pengaruh pengalamn petani dan pengaruh orang lain terhadap adopsi mesin tanam rice transplanter di Kecamatan Mojolaban Kabupaten Sukoharjo. Penelitian ini bertujuan untuk 1) mengkaji pengalaman petani, pengaruh orang lain, sikap petani terhadap adopsi mesin tanam rice transplanter dan adopsi petani terhadap mesin tanam rice transplanter di Kecamatan Mojolaban Kabupaten Sukoharjo, 2) mengkajipengaruh pengalaman petani, pengaruh orang lain dan sikap secara parsial dan simultan terhadap adopsi mesin tanam rice transplanter di Kecamatan Mojolaban Kabupaten Sukoharjo.

\section{METODE PENELITIAN}

Penelitian ini dilakukan dengan menggunakan metode penelitian kuantitatif. Pemilihan lokasi penelitian dilakukan secara purposive.Lokasi yang dipilih adalah Kecamatan Mojolaban yang mendapatkan bantuan mesin tanam rice transplanter terbanyak di bandingkan kecamatan lainnya di Kabupaten Sukoharjo. Kemudian diambil 5 desa (Desa Klumprit, Desa Sapen, Desa Joho, Desa Dukuh, Desa Palur) yang memiliki mesin tanam rice transplanter dengan 17 kelompok tani.

Teknik pengambilan sampel dilakukan dengan proportional random sampling dengan jumlah sampel sebanyak 60 responden.Jenis data yang digunakan dalam penelitian ini adalah data primer dan sekunder.Teknik pengumpulan data dilakukan dengan observasi, wawancara dan dokumentasi. Metode analisis data menggunakan path analysis, selain itu dilkukan uji lainnya yaitu uji validitas dengan pengambilan sampel sebanyak 20 responden dengan nilai $r$ tabel sebesar 0,444 , uji reliabilitas yang diukur dengan ketentuan nilai cronbach alpha> 0,60. Hasil uji reliabilitas penelitian ini sebesar $0,962>0,60$ yang berarti bahwa data penelitian reliable.Sebelum dilakukannya path analysisdilakukan uji asumsi klasik terlebih dahulu yakni, uji normalitas, uji 
multikolinearitas dan uji heteroskedestisitas. Berdasarkan hasil uji asumsi klasik menunjukkan bahwa penelitia ini sudah memenuhi syarat untuk kemudian dianalisis menggunakan path analysis.

\section{HASIL DAN PEMBAHASAN}

Pangan sebagai kebutuhan utama manusia yang terus mengalami peningkatan kebutuhan membutuhkan penanganan yang serius.Pemerintah berupaya menetapkan Pencapaian Swasembada Berkelanjutan Padi, Jagung dan Kedelai. Hal tersebut ditindaklanjuti dengan mentri pertanian mengeluarkan Pedoman Upaya Khusus (UPSUS) Peningkatan Produksi Padi, Jagung dan Kedelai melalui Program perbaikan jaringan Irigasi dan Sarana Pendukungnya yang tertuang dalam Peraturan Mentri Pertanian Republik Indonesia Nomor 03/Permentan/OT.140/2/2015. Salah satu tujuan dibuatnya pedoman tersebut untuk menyediakan kebutuhan prasarana dan sarana pertanian berupa air irigasi, benih, pupuk dan alat mesin pertanian (alsintan) dan sarana produksi lainnya.

Ditjen Prasarana dan Sarana Pertanian, Kementrian Pertanian Republik Indonesia memberikan bantuan sejumlah alat mesin pertanian kepada seluruh kelompok tani, gapoktan, UPJA (Usaha Pelayanan Jasa Alsintan) dan P3A (Perkumpulan Petani Pemakai Air) di Kabupaten Sukoharjo. Bantuan berupa hand trakktor, traktor roda 4 , rice transplanter dan empat unit pompa air. Bantuan tersebut sebagai bentuk apresiasi karena kelompok ini berhasil dalam budidaya padi. Total bantuan alat pertanian yang diserahkan dari APBN 2017 yakni 3 unit traktor roda 4, 125 unit hand traktor,5 unit transplanter dan 85 unit pompa air juga bantuan alat pertanian seperti combine harvester (alat pemanen padi), rice transplanter (mesin tanam padi) dan power thresher (alat perontok padi) (sukoharjokab.co.id).

Kecamatan Mojolaban merupakan kecamatan yang memiliki jumlah bantuan berupa mesin tanam rice transplanter terbanyak di Kabupaten Sukoharjo. Menurut data Dinas Pertanian dan Perikanan Kabupaten Sukoharjo terdapat 8 mesin tanam rice transplanter di Kecamatan Mojolaban. Mesin tersebut tersebar ke beberapa desa yaitu Desa Klumprit 1 unit mesin, Desa Sapen 1 unit mesin, Desa Joho 1 unit mesin, Desa Dukuh 4 unit mesin dan Desa Palur 1 unit mesin. Mesin tanam tersebut didistribusikan ke salah satu kelompok tani yang berada di desa yang bersangkutan.

Pengalaman Petani, Pengaruh Orang Lain, Sikap terhadap Adopsi Mesin Tanam Rice Transplanter dan Adopsi terhadap Mesin Tanam Rice Transplanter

\section{Pengalaman Petani}

Sesuatu yang telah dan sedang kita alami akan ikut membentuk dan mempengaruhi penghayatan kita terhadap stimulus sosial. Tanggapan akan menjadi salah satu dasar terbentuknya sikap. Tetapi untuk dapat mempunyai tanggapan dan penghayatan, seseorang harus mempunyai pengalaman yang berkaitan dengan objek psikologis. Penghayatan itu kemudian akan membentuk sikap positif atau negatif tergantung faktor lain (Azwar, 1988).

Tabel 1. Distribusi Responden Berdasarkan Pengalaman Petani

\begin{tabular}{llcrr}
\hline \multirow{2}{*}{ No } & \multirow{2}{*}{ Kategori Pengalaman Petani } & Skor & D & Persentase (\%) \\
\cline { 3 - 5 } 1 & Rendah & $8,0-14,8$ & 34 & 56,7 \\
2 & Sedang & $14,9-21,7$ & 24 & 40,0 \\
3 & Tinggi & $21,8-28,6$ & 2 & 3.3 \\
4 & Sangat Tinggi & $28,7-35,5$ & 0 & 0,0 \\
\hline & Jumlah & 60 & 100,0 \\
\hline
\end{tabular}

Berdasarkan Tabel 1dapat dilihat bahwa pengalaman petani bekerja disektor pertanian padi di Kecamatan Mojolaban adalah mayoritas berada pada kategori rendah.Artinya bahwa mayoritas petani responden memiliki pengalaman yang rendah meliputi lamanya responden berusaha 
tani padi, lamanya responden ikut serta dalam kelompok tani, lamanya responden menggunakan mesin tanam, pengalaman gagal dalam berusaha tani padi, serta tingkat keikutsertaan responden dalam program pemerintah.

\section{Pengaruh Orang Lain}

Salah satu faktor yang membentuk sikap seseorang terhadap sesuatu hal yaitu orang lain yang dianggap penting yang seringkali mempengaruhi seseorang untuk mengambil keputusan. Pada umumnya individu cenderung untuk memiliki sikap yang searah dengan sikap orang yang dianggapnya penting (Azwar, 1988).

Tabel 2. Distribusi Responden Berdasarkan Pengaruh Orang Lain

\begin{tabular}{llccr}
\hline \multirow{2}{*}{ No } & Pengaruh orang lain & Skor & N & Pistribusi \\
\cline { 3 - 5 } & & & 10 & 16,7 \\
2 & Tidak Pernah & $31,0-69,6$ & 47 & 78,3 \\
3 & Serang & $69,7-108,3$ & 3 & 5,0 \\
4 & Selalu & $108,4-147,0$ & 0 & 0,0 \\
\hline & Jumlah & $147,1-185,7$ & 60 & 100,0 \\
\hline
\end{tabular}

Berdasarkan Tabel 2 dapat dilihat bahwa pengaruh orang lain dalam penelitian ini tergolong jarang berpengaruh. Pada penelitian ini pengaruh orang lain terdiri dari pengaruh keluarga, petani lain, tokoh masyarakat, kelompok tani dan PPL kepada petani dalam pengambilan keputusan, memberikan masukan serta seringnya masukan tersebut dipatuhi oleh petani respoden. Mayoritas petani dalam penelitian ini berada pada kedudukan jarang dalam hal menilai pengaruh pihak-pihak tersebut. Hal tersebut karena mayoritas petani jarang melakukan interaksi dengan pihak-pihak tersebut, karena seringkali mampu menyelesaikan persoalannya sendiri. Petani lain berdasarkan penelitian adalah yang paling sering responden temui dan memberikan berbagai informasi.

\section{Sikap Petani terhadap Adopsi Mesin Tanam Rice Transplanter}

Sikap adalah kecenderungan untuk merespon baik atau tidak baik terhadap suatu objek, orang, institusi atau acara, Ajzen (1988) dalam Sarwono (2002).Sikap mengandung tiga komponen.Ketiga komponen tersebut yaitu kognitif (pengetahuan), afektif (sikap) dan konatif (keterampilan).Distribusi sikap petani pada penelitian ini dapat dilihat pada Tabel 3.

Tabel 3. Distribusi Responden Berdasarkan Sikap Petani

\begin{tabular}{llcrr}
\hline \multirow{2}{*}{ No } & Kategori Sikap Petani & \multirow{2}{*}{ Skor } & \multicolumn{2}{c}{ Distribusi Sikap } \\
\hline 1 & Sikap Kognitif & & & Prosentase (\%) \\
& Tidak setuju & $5-9$ & 5 & 8,3 \\
& Kurang setuju & $\mathbf{9 , 1}-\mathbf{1 3 , 1}$ & $\mathbf{2 2}$ & $\mathbf{3 6 , 7}$ \\
& Setuju & $\mathbf{1 3 , 2}-\mathbf{1 7 , 2}$ & $\mathbf{2 2}$ & $\mathbf{3 6 , 7}$ \\
& Selalu & $17,3-21,3$ & 11 & 18,3 \\
\hline & & 60 & 100,0 \\
\hline
\end{tabular}




\begin{tabular}{lccr}
\hline 2 Sikap Afektif & & & \\
Tidak setuju & $10-20,5$ & 12 & 20 \\
Kurang setuju & $\mathbf{2 0 , 6}-\mathbf{3 1 , 1}$ & $\mathbf{2 9}$ & $\mathbf{4 8 , 3}$ \\
Setuju & $31,2-41,7$ & 15 & 25 \\
Selalu & $41,8-52,3$ & 4 & 6,7 \\
\hline Jumlah & & 60 & 100,0 \\
\hline Sikap Konatif & $7-14$ & & 16,7 \\
Tidak setuju & $\mathbf{1 4 , 1}-\mathbf{2 1 , 1}$ & $\mathbf{3 2}$ & $\mathbf{5 3 , 3}$ \\
Kurang setuju & $21,2-28,2$ & 13 & 21,7 \\
Setuju & $28,3-35,3$ & 5 & 8,3 \\
Selalu & & 60 & 100,0 \\
\hline Jumlah & & 10 & 16,7 \\
Sikap Total & $22-45,3$ & $\mathbf{3 2}$ & $\mathbf{5 3 , 3}$ \\
Tidak setuju & $\mathbf{4 5 , 4 - 6 7 , 8}$ & 15 & 25 \\
Kurang setuju & $67,9-91,2$ & 3 & 5 \\
Setuju & $91,3-114,6$ & 60 & 100 \\
\hline Selalu & & &
\end{tabular}

Berdasarkan Tabel 3 dapat diketahui afektif petani mengenai keberadaan mesin tanam bahwa sikap petani tergolong kategori kurang tersebut adalah kurang setuju. Petani percaya setuju.Mayoritas responden memiliki sikap bahwa mesin tersebut tidak terlalu memberikan yang kurang setuju dengan mesin tanam rice manfaat yang banyak untuk membantu pekerjaan transplanter.Komponen kognitif sikap terhadap petani dalam menanam bibit padi di sawah. adanya mesin tanam rice transplanter adalah apa Kepercayaan petani yang kurang setuju dengan saja yang dipercayai seseorang mengenai mesin mesin tanam ini, maka akan membentuk perasaan tanam tersebut. Apa yang di percayai petani responden terhadap masukan mengenai mesin tanam tersebut terpolakan dalam fikirannya. Sikap kognitif petani responden kurang setuju lebih kearah setuju. Sikap setuju tersebut yang sudah terbentuk mengenai mesin tanam rice transplanter dapat menjadi dasar kepercayaan bahwa segala sesuatu yang menyangkut mesin tanam tersebut akan baik. Apabila sikap positif ini sudah tertanam sejak lama maka akan sulit untuk menerima perubahan.

Komponen afektif menyangkut masalah emosional subjektif seseorang terhadap suatu objek sikap. Reaksi emosional yang merupakan komponen afektif banyak dipengaruhi oleh kepercayaan atau apa yang dipercayai sebagai benar atau berlaku bagi objek tersebut (Azwar, 1995). Berdasarkan Tabel 3. diketahui bahwa sikap tidak suka terhadap keberadaan mesin tanam.

Komponen konatif dalam struktur sikap menunjukkan bagaimana perilaku atau kecenderungan berperilaku yang ada dalam diri seseorang berkaitan dengan objek sikap yang dihadapinya. Kepercayaan dan perasaan banyak mempengaruhi perilaku (Azwar, 1995). Berdasarkan penelitian yang dilakukan, petani responden mempunyai sikap yang kurang setuju dengan adanya mesin tanam rice transplanter. Hal tersebut dikarenakan kondisi lahan petani responden tidak sesuai dengan spesifikasi yang dimiliki mesin tanam rice transplanter, serta keterbatasan jumlah mesin di lingkungan mereka. Selain itu, petani merasa selama masih ada buruh tanam, maka petani lebih memilih menggunakan buruh tanam yang telah dilakukan secara turun temurun. 
Adopsi Petani Terhadap Inovasi Mesin Tanam Rice Transplanter

Adopsi adalah proses mental dalam proses mengambil keputusan untuk menerima atau menolak ide baru dan menegaskan lebih lanjut tentang penerimaan dan penolakan ide baru tersebut (Rogers, 1983). Salah satu inovasi dalam penelitian ini adalah mesin tanam rice transplanter. Penerapan mesin oleh petani dapat diketahui melalui beberapa komponen sebagai berikut:

Persyaratan Lahan yang dibutuhkan untuk menggunakan mesin tanam rice transplanter

Tabel 4. Distribusi Responden Berdasarkan Persyaratan Lahan

\begin{tabular}{|c|c|c|c|c|}
\hline \multirow{2}{*}{ No } & \multirow{2}{*}{ Persyaratan lahan } & \multirow{2}{*}{ Skor } & \multicolumn{2}{|c|}{ Distribusi } \\
\hline & & & $\mathrm{N}$ & Persentase $(\%)$ \\
\hline 1 & Tidak Pernah & 1 & 2 & 3,3 \\
\hline 2 & Jarang & 2 & 17 & 28,3 \\
\hline 3 & Sering & 3 & 35 & 58,3 \\
\hline 4 & Selalu & 4 & 6 & 10,0 \\
\hline & Jumlah & & 60 & 100,0 \\
\hline
\end{tabular}

Berdasarkan Tabel 4 dapat dilihat bahwa mayoritas responden sering memenuhi anjuran persyaratan lahan dalam budidaya padi.Hal ini berarti bahwa mayoritass petani responden melakukan kegiatan budidaya pertanian sesuai dengan kriteria persyaratan lahan, meliputi mengkondisikan lahan dalam keadaan melumpur sempurna dengan kedalaman lumpur kurang dari

\section{Persyaratan Bibit}

Persyaratan bibit perlu dipenuhi guna dapat menggunakan mesin tanam rice transplanter dengan baik.Persyaratan bibit yang digunakan untuk menanam padi di sawah dengan membuat persemaian berupa dapog. $25 \mathrm{~cm}$.

Tabel 5. Distribusi Responden Berdasarkan Persayaratan Bibit

\begin{tabular}{llccr}
\hline \multirow{2}{*}{ No } & Persyaratan Bibit & Skor & Distribusi \\
\cline { 4 - 5 } & Tidak Pernah & 1 & 35 & Persentase (\%) \\
2 & Jarang & 2 & 8 & 58,3 \\
3 & Sering & 3 & 12 & 13,3 \\
4 & Selalu & 4 & 5 & 20,0 \\
\hline & Jumlah & & 60 & 8,3 \\
\hline
\end{tabular}

Berdasarkat Tabel 5 dapat dilihat bahwa persyaratan bibit yang dilakukan petani dalam melakukan budidaya padi pada kategori tidak pernah.Mereka terbiasa menggunakan sistem sebar yang sudah dilakukan secara turun dan temurun, serta lebih mudah menggunakan sistem ini.
Mengoperasikan Mesin

Mengoperasikan mesin tanam rice transplanter yaitu penerapan mesin mengenai tata cara menghidupkan menjalankan serta mematikan mesin tanam. 
Tabel 6. Distribusi Responden Berdasarkan Mengoperasikan Mesin

\begin{tabular}{llccr}
\hline \multirow{2}{*}{ No } & \multirow{2}{*}{ Mengoperasikan Mesin } & \multirow{2}{*}{ Skor } & \multicolumn{2}{c}{ Distribusi } \\
\cline { 3 - 5 } & & & (Orang) & Persentase (\%) \\
\hline 2 & Tidak Pernah & $7-11,5$ & 48 & 80 \\
3 & Jarang & $11,6-16,1$ & 2 & 3,3 \\
4 & Sering & $16,2-20,7$ & 8 & 13,3 \\
\hline & Jumlah & $20,8-25,3$ & 2 & 3,3 \\
\hline
\end{tabular}

Berdasarkat Tabel 6 dapat dilihat bahwa dalam mengoperasikan mesin tanam petani tegolong dalam kategori tidak pernah. Mayoritas petani responden lebih memilih tanam menggunakan sistem konvensional (tandur) dibanding tanam dengan menggunakan mesin.

\section{Pelaksanaan Tanam}

Penanaman adalah meletakkan suatu benih atau bibit tanaman pada area tertentu yang telah dipersiapkan terlebih dengan bantuan manusia yang dapat dilakukan secara tradisional maupun modern.

Tabel 7. Distribusi Responden Berdasarkan Pelaksanaan Tanam

\begin{tabular}{llccr}
\hline \multirow{2}{*}{ No } & \multirow{2}{*}{ Pelaksanaan Tanam } & Skor & Distribusi \\
\cline { 4 - 5 } & & & (Orang) & Persentase (\%) \\
\hline 2 & Tidak Pernah & $2-3,3$ & 32 & 53,3 \\
3 & Jarang & $3,4-4,7$ & 4 & 6,7 \\
4 & Sering & $4,8-6,1$ & 23 & 38,3 \\
\hline & Jumlah & $6,2-7,5$ & 1 & 1,7 \\
\hline
\end{tabular}

Berdasarkat Tabel 7 dapat dilihat bahwa dalam pelaksanaan tanam menggunakan mesin tanam tegolong dalam kategori tidak pernah.Hal ini menunjukkan bahwa mayoritas petani responden

Tabel 8. Distribusi Responden Berdasarkan Hasil Penerapan melakukan pelaksanaan tanam padi tidak pernah menggunakan mesin tanam rice transplanter.

\section{Hasil Penerapan}

\begin{tabular}{llccr}
\hline \multirow{2}{*}{ No } & \multirow{2}{*}{ Hasil Penerapan } & \multirow{2}{*}{ Skor } & \multicolumn{2}{c}{ Distribusi } \\
\cline { 4 - 5 } & & $3-5,4$ & 18 & Persentase (\%) \\
\hline 1 & Tidak Pernah & $5,5-7,9$ & 22 & 30,0 \\
2 & Jarang & $8-10,4$ & 13 & 36,7 \\
3 & Sering & $10,5-12,9$ & 7 & 21,7 \\
4 & Selalu & & 60 & 11,7 \\
\hline & Jumlah & & 100,0 \\
\hline \hline
\end{tabular}

Berdasarkat Tabel 8 dapat dilihat bahwa hasil penerapan menggunakan mesin tanam rice transplanter menunjukkan bahwa mayoritas petani jarang.Hal tersebut berarti bahwa hasil penerapan dari adanya mesin tanam rice transplanter mayoritas petani berada pada kategori jarang, yang meliputi melakukan perhitungan analisis pengeluaran dan pendapantan di bidang pertanian dalam satu tahun terakhir serta melakukan evaluasi setiap musimnya.Hal ini karena petani tidak terbiasa melakukan analisis usaha tani yang dilakukannya. 
Pengaruh Pengalaman Petani dan Pengaruh Orang Lain Secara Simultan dan Parsial Terhadap Adopsi Mesin Tanam Rice Transplnater

Tabel 9. Nilai Penghitungan Koefisien Analisis Jalur Pengalaman Petani Dan Pengaruh Orang Lain terhadap Adopsi Mesin Tanam Rice Transplanter
Pengaruh Pengalaman Petani dan Pengaruh Orang Lian terhadap Adopsi Mesin Tanam Rice Transplnater

\begin{tabular}{lccr}
\hline Variabel & C.R & P & Keterangan \\
Sikap <-- Pengaruh Orang Lain & 3,304 & 0,001 & Signifikan \\
Adopsi $<-$ Pengalaman Petani & 3,536 & 0,001 & Signifikan \\
Adopsi $<-$ Pengaruh Orang Lain & $-0,233$ & 0,816 & Tidak Signifikan \\
Adopsi $<-$ Sikap & 9,986 & 0,000 & Signifikan \\
\hline
\end{tabular}

Berdasarkan Tabel 9. dapat dilihat bahwa bahwa $p$ value pada variabel pengalaman petani terhadap sikap petani sebesar0,323. Artinya bahwa $p$ value $>\alpha$, yaitu $0,323>0,05$. Berdasarkan perbandingan tersebut maka Ho diterima dan H1 ditolak. Hal ini berarti bahwa pengalaman petani tidak berpengaruh signifikan terhadap sikap petani dengan tingkat kepercayaan $95 \%$.

Nilaip value pada variabel pengaruh orang lain terhadap sikap petani sebesar 0,001 . Artinya bahwa $p$ value $<\alpha$, yaitu $0,001<0,05$. Berdasarkan perhitungan tersebut maka Ho ditolak dan H1 diterima. Hal ini berarti bahwa pengaruh orang lain berpengaruh signifikan terhadap sikap petani.
Nilai $p$ value pada variabel pengalaman petani terhadap adopsi mesin sebesar 0,001. Artinya bahwa $p$ value $<\alpha$, yaitu $0,001<0,05$. Berdasarkan perbandingan tersebut maka Ho ditolak dan H1 diterima. Hal ini berarti bahwa pengalaman petani berpengaruh signifikan terhadap adopsi mesin. Nilai $p$ value pada variabel pengaruh orang lain terhadap adopsi mesin sebesar 0,816. Artinya bahwa $p$ value $>\alpha$, yaitu $0,816>0,05$. Berdasarkan perhitungan tersebut maka Ho diterima dan H1 ditolak.Hal ini berarti bahwa pengaruh orang laintidak berpengaruh signifikan terhadap adopsi mesin tanam rice transplanter.

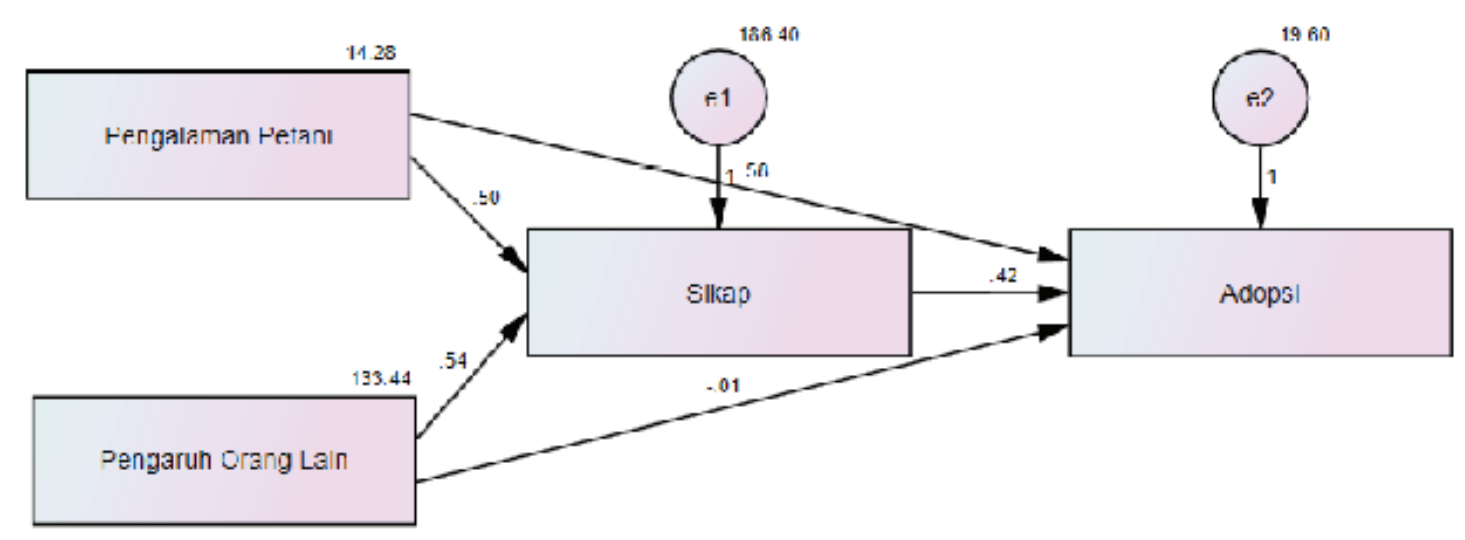

Gambar 1. Hasil Model Persamaan Analisis Jalur

Berdasarkan Gambar 1dapat diketahui bahwa pengalaman petani, pengaruh orang lain dan sikap petani secara bersama-sama mempengaruhi adopsi mesin tanam rice transplanter sebesar 19,60. Artinya, sebesar 19,60\% adopsi mesin tanam rice transplanter dipengaruhi oleh pengalaman petani, pengaruh orang lain dan sikap petani. Sisanya sebesar $80,40 \%$ dipengaruhi oleh faktor lainnya, yaitu waktu, sistem sosial dan kualifikasi penyuluh. 


\section{Pengaruh Langsung, Tidak Langsung dan Total Pengaruh}

Tabel 10. Efek Terstandarisasi Antar Variabel

\begin{tabular}{lccr}
\hline Variabel & Pengaruh & Pengaruh Tidak Langsung & Total Pengaruh \\
\hline Pengalaman Petani & 0,267 & 0,096 & 0,363 \\
Pengaruh Orang Lain & $-0,019$ & 0,322 & 0,303 \\
Sikap & 0,775 & 0,000 & 0,775 \\
\hline
\end{tabular}

Berdasarkan Tabel 10 dapat dilihat bahwa bahwa pengaruh tidak langsung pengalaman petani dan pengaruh orang lain melalui sikap lebih besar dari pada pengaruh langsung. Hal ini menunjukkan bahwa pengalaman petani berusaha tani padi dan pengaruh orang lain mempengaruhi sikap mereka terhadap suatu inovasi. Kemudian sikap tersebut akan mempengaruhi mereka terhadap adopsi mesin tanamrice transplanter.

\section{KESIMPULAN DAN SARAN}

\section{Kesimpulan}

Pengalaman petani di Kecamatan Mojolaban yaitu rendah, pengaruh orang lain yaitu jarang, sikap petani terhadap adopsi mesin tanam rice transplanter yaitu kurang setuju dan adopsi petani terhadap mesin tanam rice transplanter yaitu tidak pernah (rendah) mengadopsi. Secara parsial pengalaman petani berpengaruh signifikan terhadap adopsi mesin tanam rice transplanter secara langsung lebih besar jika dibandingkan melalui sikap, pengaruh orang lain berpengaruh tidak signifikan terhadap adopsi mesin tanam rice transplanter dan sikap petani berpengaruh signifikan terhadap adopsi mesin tanam rice transplanter di Kecamatan Mojolaban Kabupaten Sukoharjo. Pengalaman petani, pengaruh orang lain dan sikap secara simultan berpengaruh signifikan terhadap adopsi mesin tanam rice transplanter di Kecamatan Mojolaban Kabupaten Sukoharjo.

\section{Saran}

Petani perlu meningkatkan pengalaman berusahatani seperti melakukan studi banding ataupun yang lainnya sehingga petani dapat melihat hasil pertanian petani daerah lain sehingga menumbuhkan semangat yang lebih untuk membudidayakan padi agar hassilnya lebih optimal. Sikap petani yang masih kurang setuju terhadap adopsi mesin tanam rice transplanter dikarenakan lahan tidak sesuai dengan spesifikasi mesin tanam rice transplanter (lahan terlalu dalam), sehingga dalam mengajukan proposal petani perlu mencantumkan spesifikasi lahan mereka.Terkait dengan bantuan mesin tanam rice transplanter, sebaiknya pemerintah lebih disesuaikan dengan keadaan wilayah, luas lahan serta kedalaman lahan setempat supaya tepat sasaran.

\section{DAFTAR PUSTAKA}

Azwar S. 1988. Sikap Manusia Teori dan Pengukurannya. Yogyakarta: Pustaka Pelajar.

Azwar S. 1995. Sikap dan Perilaku. Dalam: Sikap Manusia Teori dan. Pengukurannya. Yogyakarta: Pustaka Pelajar.

Badan Litbang Pertanian. 2014. Petunjuk Teknis Penggunaan Indo Jarwo Transplanter Sebagai Mesin Tanam Padi Di Lahan Sawah. http://lampung.litbang.pertanian. go.id/ind/images/stories/publikasi/brosur/ juknisjarwo.pdf. Diakses pada tanggal 9 Agustus 2018.

Dwi N V. 2011. Hubungan Karakteristik Petani dengan Tingkat Adopsi Petani dalam Sekolah Lapang Iklim (SLI) di Kabupaten Blora.Skripsi. Universitas Sebelas Maret: Surakarta.

Hapsari P. 2018.Adopsi Teknologi Rice Transplanter (Studi Deskriptif Kualitatif Adopsi Teknologi Pertanian Rice Transplanter Di Desa Wironanggan, Gatak, Sukoharjo dengan Pendekatan Difusi Inovasi). Naskah Publikasi. Univesitas Muhammadiyah Surakarta: Surakarta. 
Harinta Y W. 2010. Faktor-Faktor Yang Mempengaruhi Kecepatan Adopsi Inovasi Pertanian Di Kalangan Petani Di Kecamatan Gatak Kabupaten Sukoharjo. Skripsi. Universitas Sebelas Maret: Surakarta.

https://portal.sukoharjokab.go.id/2018/03/12/ hadiri-panen-raya-padi-bupati-sukoharjoserahkan-bantuan-alsintan $\% E 2 \% 80 \% 8 E /$. diakses pada tanggal 11 Agustus 2018

Mar'at. 1982. Sikap Manusia, Perubahan serta Pengukurannya. Jakarta: Ghalia Indonesia.

Mardikanto T, S Sutarni.1982. Pengantar Penyuluhan Pertanian dalam Teori dan Praktek. Surakarta: Hapsari.

Permentan.2015. Peraturan Menteri Pertanian Nomor 14/Permentan/OT.140/3/2015 TentangPedoman Pengawalan Dan Pendampingan Terpadu Penyuluh, Mahasiswa, Dan Bintara Pembina Desa Dalam Rangka Upaya Khusus Peningkatan Produksi Padi, Jagung, Dan Kedelai. Kementerian Pertanian. Kementerian Pertanian: Jakarta.

Prabayanti H. 2010. Faktor-Faktor Yang Mempengaruhi Adopsi Biopestisida Oleh Petani Di Kecamatan Mojogedang Kabupaten Karanganyar.Skripsi. Universitas Sebelas Maret: Surakarta.

Rahmawati N, S Anantanyu, A Wijianto. 2016. Sikap Petani Terhadap Inovasi Mesin Rice Transplanter Di Kecamatan Juwiring Kabupaten Klaten. Jurnal Agritexts. Vol. 40 : 114-128.

Rogers E M. 1983.Diffusion of Innofations Third Edition. New York: The Free Press.

Romadi U, D Lusianto. 2016. Persepsi Petani Padi Terhadap Pemanfaatan Rice Transplanter Di Kecamatan Pohjentrek Kabupaten Pasuruan Provinsi Jawa Timur.Jurnal Agrica Ekstensia. Vol. 10 (2): 61-66.

Sarwono S W. 2002. Psikologi Sosial Individu dan Teori-teori Psikologi Sosial. Jakarta: Balai Pustaka.
Soetriono, A Suwandari, Rijanto. 2006. Pengantar Ilmu Pertanian. Malang: Bayumedia Publishing

Sundari. 2014. Rice Transplanter dapat mempercepat waktu tanam bibit padi. $h t t p: / /$ cybex.pertanian.go.id/materipenyuluhan/ detail/9591/rice-transplanter-dapatmempercepat-waktu-tanam-bibit-padi. Diakses pada tanggal 11 Agustur 2018

Yuwono T, et al. 2011. Pembangunan Pertanian: Membangun Kedaulatan Pangan. Yogyakarta: Gajah Mada University Press. 